\title{
Brexit and tariff rate quotas on EU imports: a complex problem
}

\author{
by Revell, B.J.
}

Copyright, Publisher and Additional Information: This is the author accepted manuscript. The final published version (version of record) is available online via Wiley. This article may be used for non-commercial purposes in accordance with Wiley Terms and Conditions for Self-Archiving

DOI: https://dx.doi.org10.1111/1746-692X.12157

Revell, B.J. 2017. Brexit and tariff rate quotas on EU imports: A complex problem. EuroChoices, 16(2), pp.10-17. 


\title{
Brexit and Tariff Rate Quotas on EU Imports: A Complex Problem
}

\author{
Brian Revell
}

This article outlines some of the issues regarding approaches the EU27 and UK may need to adopt in establishing their respective trade commitments through the World Trade Organisation (WTO). In particular, it focuses on matters surrounding the EU28 Tariff Rate Quotas (TRQs), especially those relating to livestock products. From a UK perspective these are products perceived as being vulnerable to external competition. The article first explains the present situation regarding TRQs in the EU28, the use the UK makes of them, and the levels of third country (non EU) imports of meat and dairy products, as these will be the starting point for future Brexit negotiations. The negotiations will need to address how third country exporters will access both the EU27 and the UK markets post Brexit, as in the absence of a customs union, their conditions of preferential access to the UK and EU27 could change.

\section{The role of TRQs}

The TRQ is a key instrument for the management and control of external competition in the EU28's agri-food sector. It is a mechanism by which preferential access for imports of specific quantities of a product is granted at a given tariff rate, which can be zero. Quotas may be allocated to individual countries or to a group of countries, or a global quota can be made available to all countries. Beyond the specified overall quota, an out of quota (higher tariff) is imposed on all additional imports without favour or preference. The appeal of the TRQ, it is argued, is that it circumvents GATT and subsequent WTO principles that generally prohibit quantitative restrictions and discrimination in trade. It does so by ensuring that a Most Favoured Nation (MFN) tariff applies without discrimination to all potential suppliers, once quotas with preferential tariff concessions are filled. However, depending on the level of in-quota tariff or the allocated quota, TRQs can still render exporting within a TRQ commercially unattractive, whilst MFN tariffs rates are frequently prohibitive.

The EU28 has around 87 TRQ schemes for agricultural, food and beverage products which, depending on how they are counted, comprise well-over 120 separate individual tariff quotas. This compares with 54 TRQs in the USA and 21 in Canada. Since the review of EU TRQs by Bureau and Tangermann (2000), quotas for a range of products have been increased to reflect EU enlargement, and further TRQs have been created in relation to EU Association Agreements and Free Trade or Regional Trade Agreements (FTAs and RTAs), such as the recently concluded EU-Canadian Comprehensive Economic and Trade Agreement (CETA).

\section{Implications of Brexit}

A range of informed commentators from international lawyers, economists, and former WTO officials, have recognized that in the context of Brexit there will be a need to separate the current EU28 TRQ commitments, which the Commission has negotiated on behalf of all Member States, into UK and EU27 components. This will require agreement not only between the EU27 and UK, but also with third country exporters, both current and potential, regarding market access. Commentators and analysts have observed that 'it won't be sorted out quickly' (Ungphakorne 2016a); 'pretty complicated, if not downright murky' (Ungphakorne 2016b); ' a complex journey' (Hestermayer and Ortino, 2016); ' $a$ thorny problem' (Downes, 2016). The process of establishing an independent UK 
schedule of tariff commitments and TRQs within the WTO is primarily a legal matter. As there is no directly comparable precedent (only one for new WTO members, whereas the UK is already a WTO member), potential solutions remain the subject of legal opinion and debate.

\section{Background and the current position}

\section{A plethora of EU28 TRQs in the meat and dairy sectors}

Table 1 presents an overview of the relationship between in-quota and out-of-quota ad valorem equivalent_(AVE) tariff rates for a selected range of key agricultural products in 2015 incorporating both fixed ad valorem rates and specific customs duties, which are often imposed in addition. The latter can be the key prohibitive element in the total import tax.

[Table 1 about here]

There is a multiplicity of TRQ schemes for meat and dairy products, especially for beef and veal, sheep meat, pig and poultry meat and their edible offal. Further complexity is added because meat products are not homogeneous, in that they can be traded in fresh, chilled or frozen forms, as whole carcases, quarters, bone in and boneless cuts, and as salted product in the case of poultry meat. Table 2 presents a simplified version of the complex number of quota schemes in the beef and veal sector, as the range of sub-product tariffs and quotas are in fact all specified at an 8 digit Harmonized System (HS) or Common Customs tariff nomenclature. There are various special quota schemes such as the High Quality Beef and Veal (HQBV) scheme now encompassing the so-called Hilton beef quota established under the Tokyo Round GATT agreement in 1979, and the Autonomous Beef Quota ( $A B Q$ ), which was originally created in 2009 to resolve the dispute between the EU and the United States over imports of beef involving growth hormones. There is transferability (within limits) between meat which might be imported via the HQBV and the ABQ, provided it meets the quality specifications of both (AHDB, 2017a; Ungphakorne, 2016b). The HQBV quota allocates quotas to specific countries. The ABQ is restricted to the USA, Canada, New Zealand, Argentina and Uruguay, but is defined as a global quota. Imports are zero tariff-rated, whilst the other substantial quotas, HQBV, and two open to all (erga omnes) frozen beef quotas carry a 20 per cent tariff. A manufacturing beef quota also carries additional high fixed duties.

[Table 2 about here]

The sheep and goat meat TRQ is simple and totals almost 287,000 tonnes, with country specific allocations, predominantly for New Zealand (228,200 tonnes). Argentina, Australia, Chile and Uruguay have quota allocations of $23,000,19,186,7,600$ and 5,800 tonnes respectively, with a number of other countries receiving very small quotas. Only the USA and Canada have country specific quota allocations of 4,922 and 4,624 tonnes respectively out of a total of 117,413 tonnes of pig meat. All other pig meat sub-product quotas are erga omnes. Although the pig meat TRQs are zero AV tariff rated, most carry fixed customs duties, except for a single 7,000 tonne erga omnes quota and two 20,000 tonne allocations to Ukraine within the Association Agreement concluded late in 2015.

There are nine separate TRQs for chicken and turkey. Of the total of 104,467 tonnes for fresh, chilled and frozen product 21,345 tonnes are allocated to the USA, 16,632 tonnes to Brazil and 5,100 tonnes to Thailand. All the other sub-product quotas are erga omnes, although Ukraine has recently been allocated 40,000 tonnes. These poultry meat TRQs are zero AV tariff rated, but with the exception of those for Ukraine, Thailand and Brazil, all have additional specific duties attached. A salted poultry 
meat TRQ of 264,000 tonnes is allocated almost entirely to Brazil $(170,807$ tonnes) and Thailand $(92,610$ tonnes) and carries an AV tariff of 15.4 per cent.

In the dairy sector, there are separate TRQs for specific types of cheese, viz. pizza-types, Emmentaler, Gruyere, cheese for processing, Cheddar, unripened, blue veined and AOC regional speciality types. They total 117,670 tonnes; all are zero AV tariff rated but carry fixed customs duties. These raise the TRQ AVE rate to 26 per cent for Cheddar type cheese, with an MFN out-of-quota AVE rate of 45 per cent. The principal quota holders are Australia (7,500 tonnes), New Zealand (7,711 tonnes) and Canada (4,000 tonnes), the remaining quota being erga omnes. There is an 86,053 tonne TRQ for butter that is zero AV tariff rated but with a specific tariff with an AVE rate of 25 per cent compared with 69 per cent MFN out-of-quota rate. Of this quota, 74,693 tonnes are allocated to New Zealand, the remainder being erga omnes.

Table 3 illustrates the ineffectiveness of the concessionary tariffs together with the inflexibility inherent in country-specific quota allocations, in ensuring high quota fill rates. Based on the latest WTO (WTO, 2016) estimates of quota fill at the 6 digit (sub-product) level for 2013-14, aggregate product group level average fill rates varied from 2-88 per cent (author's calculation) and an estimate for 2015/16 suggests a 71 per cent fill rate for HQBV (AHDB, 2016b). The final column of Table 3 underlines the relatively low proportions of extra-EU28 imports of meat and dairy products benefitting from zero MFN or preferential tariffs, with the exception of sheep meat and cheese.

[Table 3 about here]

\section{The UK and its Extra and Intra EU28 agri-food imports}

Over the period 2013-15 the UK imported agri-food products valued at almost $€ 15$ billion from outside the EU, 11 per cent of extra-EU28 total imports by value over that period. Figure 1 shows the UK's specific product share of extra-EU28 imports by volume given that TRQs are defined in volumes rather than values. Figure 2 shows that the degree of UK self-supply in 2015 was generally high, other than for vegetables, fruit and pig meat. Moreover, apart from vegetables, fruit, and sheep meat, where imports from third countries are largely seasonal, UK import requirements are predominantly met by other EU member states.

[Figure 1 about here]

[Figure 2 about here]

Figure 3a illustrates the relationship between the UK share of extra-EU28 imports from principal TRQ holders, and their shares of UK third country imports of meat and dairy products; the bubble size represents the tonnage of product imported by the UK from these countries. Principal exporters of salted poultry meat, sheep meat, pig meat and butter have shares of UK extra-EU28 imports in excess of 85 per cent and imported tonnages are relatively high, except for butter and pig meat. UK shares of EU28 imports exceed 20 per cent for these products, except for butter. For fresh, chilled and frozen beef and poultry meat, third country imports are more modest, with principal quota holder shares of UK third country imports between 60 and 70 per cent and UK shares of EU28 imports from these exporters between 9 and 13 per cent. Figure $3 \mathrm{~b}$ illustrates the distribution of UK shares of EU28 meat and dairy product imports from the principal countries with allocated TRQs. 
They are indicative of which specific countries would have interests in a number of commodities should the UK seek to establish its own TRQs, or change the basis of TRQ allocation, which could inter alia include the total quota and/or allocated shares (e.g. erga omnes versus country allocations) and quota management (e.g. first come, first served or tendered).

[Figure $3 a$ about here]

All the trade discussed thus far has taken place under current EU tariff Schedules and concessions which afford both the EU27 and the UK a large measure of protection from imports from third countries. Clearly Brexit has the potential to alter significantly the distribution of UK import sourcing depending on the nature of the trading relationship which emerges with the EU27, the tariff schedules the UK adopts and applies; and any TRQs and trade agreements the UK might negotiate with its present principal overseas trading partners and other exporting WTO member countries such as those in Figure 3b.

[Figure $3 b$ about here]

\section{Brexit and the search for a TRQ solution}

\section{Sharing EU TRQs between the UK and EU27}

Neither the members of the EU27 nor the UK individually have quota shares, given that the TRQs have been negotiated through the GATT by the Commission on behalf of all $28 \mathrm{EU}$ member states. Indeed, it is difficult if not quite impossible to disaggregate TRQ imports to individual countries on the basis of trade statistics, given that ports such as Antwerp or Rotterdam may be the first point of arrival for container imports, the contents being broken down for subsequent transhipment to individual member states. Although Article XIII of the GATT sets the criterion for the establishment of quota shares over a representative three year period, a pro-rata division of the EU28 TRQs, perhaps somewhat akin to the UK-EU27 third country trade shares in Figure 1, might seem appealing, but is fraught with problems. TRQs divided pro rata between the UK and EU27 would imply a reduction in the present EU TRQ tonnages. The resultant smaller UK TRQs might also be insufficient to warrant separate shipments to the UK and be unattractive to some exporters transhipping through Rotterdam if tariffs on EU27-UK trade were to be applied. Furthermore, product imported into the EU28 can be sold throughout the EU no matter where landed, which would imply a loss of access and flexibility for exporters to reallocate product between member states according to local demand, even were the EU27 to leave its current TRQs unchanged post Brexit. From an EU perspective, as quota fill rates are generally well below 100 per cent, it would seem prudent for the EU27 to retain its existing commitments on TRQs, since that might avoid the possibility of challenges by exporters in the WTO and the need for dispute settlement. For the UK, the way forward may be less straightforward, having no schedule of tariffs and TRQ concessions of its own pre-Brexit.

\section{Possible options for the UK}

The outcomes of any decisions relating to post-Brexit trade arrangements and future UK agricultural and food policies are linked. For example, a post-Brexit general lowering of UK tariff protection below current applied EU levels would reduce the cost of imported foods into the UK, but conversely put downwards pressure on producer prices. This in turn could lead to demands for additional 
(decoupled) income support, especially in its vulnerable ruminant livestock sector. The creation of UK TRQs for third countries could be used to mitigate some of the effect on prices of reducing tariff levels. Furthermore it is likely that current quota holding suppliers would seek to maintain their preferential access into the UK market.

The excellent, detailed analysis by Downes (op. cit., 2016) considers the pros and cons of nonnegotiated certification by the UK of existing EU Schedules, or negotiation regarding the UK's modification of its bound commitments to meet WTO requirements. He concludes that in the long run, it would be in the best interests of the UK to negotiate its own schedules in order to give them legal status within the WTO, though this is a process that would take time. However, the UK could as an interim measure set its own applied tariffs post Brexit, provided these do not exceed existing EU MFN bound rates. Such applied tariffs would have no legal basis, but would facilitate the creation of the UK's own operational TRQs, providing there were consultations with principal exporters and other interested suppliers as required in Article XIII of the GATT. Given mutual expressions of interest by Australia, New Zealand and the USA in negotiating trade agreements with the UK postBrexit, all of which are major agricultural exporting nations delivering substantial shares of UK third country meat imports through existing TRQs (Figure $3 \mathrm{~b}$ ) this approach has much to commend it. Nevertheless it would seem unwise for the UK to squander its future trade negotiating capital by implementing large unilateral reductions in its applied MFN tariff rates immediately post Brexit. Furthermore, if, in the absence of having negotiated any post- Brexit TRQs of its own, the UK were to set its applied tariffs at rates significantly below current TRQ rates, this might potentially lead to a redistribution of market shares of existing quota holders through market forces. As an allocated TRQ confers on the holder a quantum of country preference, this could precipitate exporter complaints being raised within the WTO.

If there is a 'Hard Brexit' in which the EU and UK fail to negotiate some form of free trade agreement, the UK would have access only to the erga omnes provision of existing EU TRQs with its remaining exports attracting out of quota MFN tariff rates. This could substantially impact on UK exports to the EU of some meat products, especially sheepmeat. The EU would have access to the UK market but only at whatever applied tariff rates the UK might apply post-Brexit. However, the EU27 and UK both jointly and separately have obligations through existing TRQs to facilitate market access post-Brexit. This will apply not only to third countries, but equally to each other (as third countries) in ensuring market access. There may well be the necessity to negotiate reciprocal EU27-UK TRQs in order to preclude significant trade disruption in the event a genuine free trade agreement proves impossible to achieve.

\section{Final Comments}

There is ample evidence that international trade negotiations can take many years to complete (e.g. EU Mercosur unresolved since 2000, CETA -7 years in negotiation, Malaysia in progress since 2010, Japan, Thailand and Morocco since 2013). This article has not even touched on matters of Rules of Origin, Sanitary and Phytosanitary (SPS) standards for protecting human, animal and plant health in trade, and other nationally enforced standards that govern extra-EU imports, which would add further complications to UK-third country negotiations (see IMTA, 2016 for post Brexit non-tariff issues that will require UK EU27 resolution). Whichever track the UK takes with regard to future tariff rates and TRQs, it seems probable that it cannot avoid consultation and negotiation with trade partners. Provided that the UK approach meets WTO criteria for greater market access, it is less likely to become mired in dispute resolution or to fall-back on current bound MFN rates. Nevertheless, a swift resolution of any UK TRQs within or outside any bilateral trade agreements 
would appear to be optimistic given that both the EU27 and UK will be engaged in simultaneous and iterative rounds of negotiations with each other and with other WTO members.

\section{Further Reading:}

AHDB (2017a) EU autonomous beef quota under the spotlight.

http://beefandlamb.ahdb.org.uk/market-intelligence-news/eu-autonomous-beef-quota-spotlight/

Accessed on 18/04/2017

AHDB (2016 b) Little change in EU high-quality beef quota usage.

http://beefandlamb.ahdb.org.uk/market-intelligence-news/little-change-eu-high-quality-beef-

quota-usage/

Bureau, Jean-Cristophe and Tangermann, Stefan (2000). Tariff Rate Quotas in the EU. Agricultural

and Resource Economics Review 29/1. p 70-80

Downes, Chris, (2016) The Post-Brexit Management of EU Agricultural Tariff Rate Quotas. Available at SSRN: https://ssrn.com/abstract=2874371. (Last Accessed 18-08-2017).

Hestermeyer, Holger P. and Ortino, Federico, Towards a UK Trade Policy Post-Brexit: The Beginning of a Complex Journey (October 30, 2016). King's College London Law School Research Paper No. 2017-04. Available at SSRN: https://ssrn.com/abstract=2861488. (Last Accessed 18-08-2017).

IMTA (2016) Overview of Current UK Meat Import and Export Trade. http://www.imtauk.org/images/stories/pdf docs/imports paper/Overview\%20of\%20Current\%20UK\%20Meat\%20lm port\%20and\%20Export\%20Trade.pdf. (Last accessed 18-08-2017)

WTO (2016) Notification, Committee on Agriculture G/AG/N/EU/30 (16-4668)

Ungphakorne, Peter (2016a) Nothing simple about UK regaining WTO status post-Brexit I International Centre for Trade and Sustainable Development.

http://www.ictsd.org/opinion/nothing-simple-about-uk-regaining-wto-status-post-brexit. (Last Accessed 18-08-2017).

Ungphakorn, Peter (2016b), The Hilton beef quota: a taste of what post-Brexit UK faces in the WTO. Trade $\beta$ Blog. Updated Nov. 25, 2016. https://tradebetablog.wordpress.com/2016/08/10/hiltonbeef-quota/ . (Last Accessed 18-08-2017).

Brian Revell, Harper Adams University, UK.

Email: bjrevell@harper-adams.ac.uk 
Table 1: EU AV Equivalent MFN Tariffs on TRQ and out-of-quota UK third country imports

\begin{tabular}{|c|c|c|c|c|c|c|c|c|c|c|}
\hline & \multicolumn{3}{|c|}{ Fresh } & \multirow{2}{*}{$\begin{array}{l}\text { Fresh } \\
\text { Fruit }\end{array}$} & \multirow{2}{*}{$\begin{array}{c}\text { Beef and } \\
\text { Veal }\end{array}$} & \multicolumn{2}{|c|}{ Mutton \& } & \multicolumn{3}{|c|}{ Cheddar } \\
\hline & Wheat & Veg. & Potatoes & & & Pigmeat & Lamb & Poultry & Cheese & Butter \\
\hline Tariff quota AVE & & & & & & & & & & \\
\hline rates & $0 \%$ & $0-12 \%$ & $3 \%$ & $0-10 \%$ & $0-20 \%$ & $0-10 \%$ & $0 \%$ & $0-10 \%$ & $26 \%$ & $25 \%$ \\
\hline $\begin{array}{l}\text { Out of quota AVE } \\
\text { rates ie MFN } \\
\text { AVE rates [a] }\end{array}$ & $47 \%$ & $3-15 \%$ & $5-12 \%$ & $0-39 \%$ & $49-53 \%$ & $11-21 \%$ & $45-72 \%$ & $\begin{array}{r}12-33 \% \text { and } 51 \% \text { for } \\
\text { salted }\end{array}$ & $45 \%$ & $69 \%$ \\
\hline
\end{tabular}

Sources: UN Comtrade database for tonnages and values;

Commission Implementing Regulations 927/2012 and 2015/1754 OJ L 285/1 30.10.2015 for tariff rates.

[a] Author's calculations based on trade weighted averages of tariff rates and fixed duties and c.i.f. unit values of imports of meat and dairy products converted from \$US to $€$ at HS 6 digit level AVEs.

Table 2: The multiplicity and complexity of EU28 beef and veal TRQs

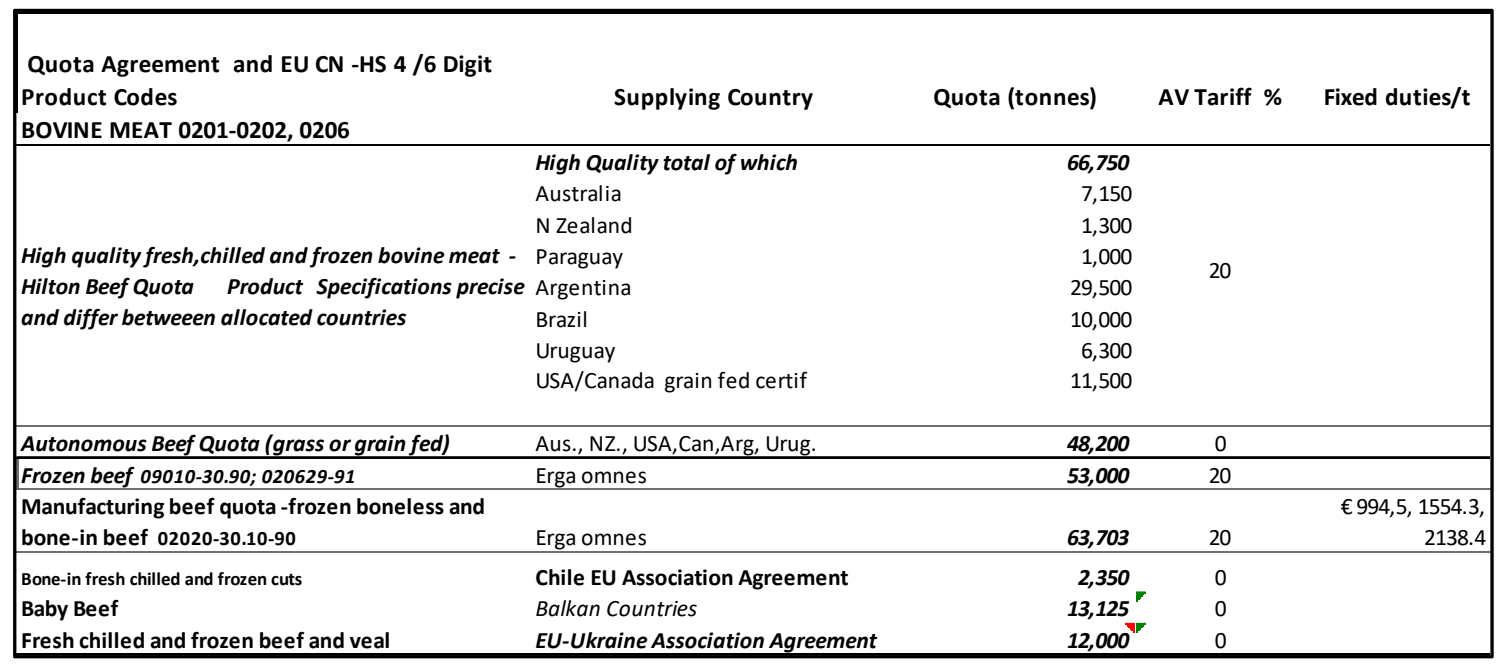

Sources: Annex 7 Commission Implementing Regulation (EU) no 927/2012 and various OJ notices regarding subsequent Agreements.

Table 3: TRQs and quota-fill estimates 2013-14 and 2015

\begin{tabular}{|lrrrrr|}
\hline & $\begin{array}{c}\text { Aggregated TRQs } \\
\text { '000 tonnes } \\
\text { product wt [a] [c] }\end{array}$ & $\begin{array}{c}\text { EU28 Imports } \\
\text { '000 tonnes } \\
\text { product wt.[b] }\end{array}$ & $\begin{array}{c}\text { EU28 Imports } \\
\text { relative to TRQ }\end{array}$ & $\begin{array}{c}\text { WTO Quota fill } \\
\text { rate estimates } \\
\text { 2013-14 [c] }\end{array}$ & $\begin{array}{c}\text { Share of EU28 } \\
\text { imports at 0\% } \\
\text { MFN or } \\
\text { Preferential } \\
\text { rates [d] }\end{array}$ \\
\hline Beef and veal & & & & & $43 \%$ \\
Sheep/goatmeat & 234,003 & 199,714 & $78 \%$ & $56 \%$ & $100 \%$ \\
Pigmeat & 286,802 & 165,739 & $58 \%$ & $88 \%$ & $60 \%$ \\
Poultrymeat & 117,413 & 8,216 & $7 \%$ & $2 \%$ & $39 \%$ \\
Salted Poultrymeat & 104,467 & 154,559 & $157 \%$ & $67 \%$ & $1 \%$ \\
Butter & 264,245 & 265,406 & $100 \%$ & $81 \%$ & $2 \%$ \\
All Cheese & 86,053 & 24,470 & $28 \%$ & $31 \%$ & $18 \%$ \\
\hline
\end{tabular}

Sources:[a] Appendix 7 Commission implementing Regulation (EU) 927/2012; Lionel Colby and AHDB for updates

[b] EU trade since 1988 by HS2,4,6 and CN8 [DS-645593];http://ec.europa.eu/eurostat/web/international-trade-in-goods/data/database

[c] WTO Committee on Agriculture Notification G/AG/N/EUJ/30 (imports under tariff quotas for marketing year 2013/14 and calendar year 2014), 2/09/2016

[d] Adjusted Extra-EU imports by tariff regime, by HS6 (DS-041718). [d] Adjusted EU-EXTRA imports by tariff regime, by HS6 (DS-041718)

[b] and [d] last accessed at http://ec.europa.eu/eurostat/web/international-trade-in-goods/data/database on 18/04/17 
Figure 1: UK share of Extra-EU28 agri-food product trade 2013-15

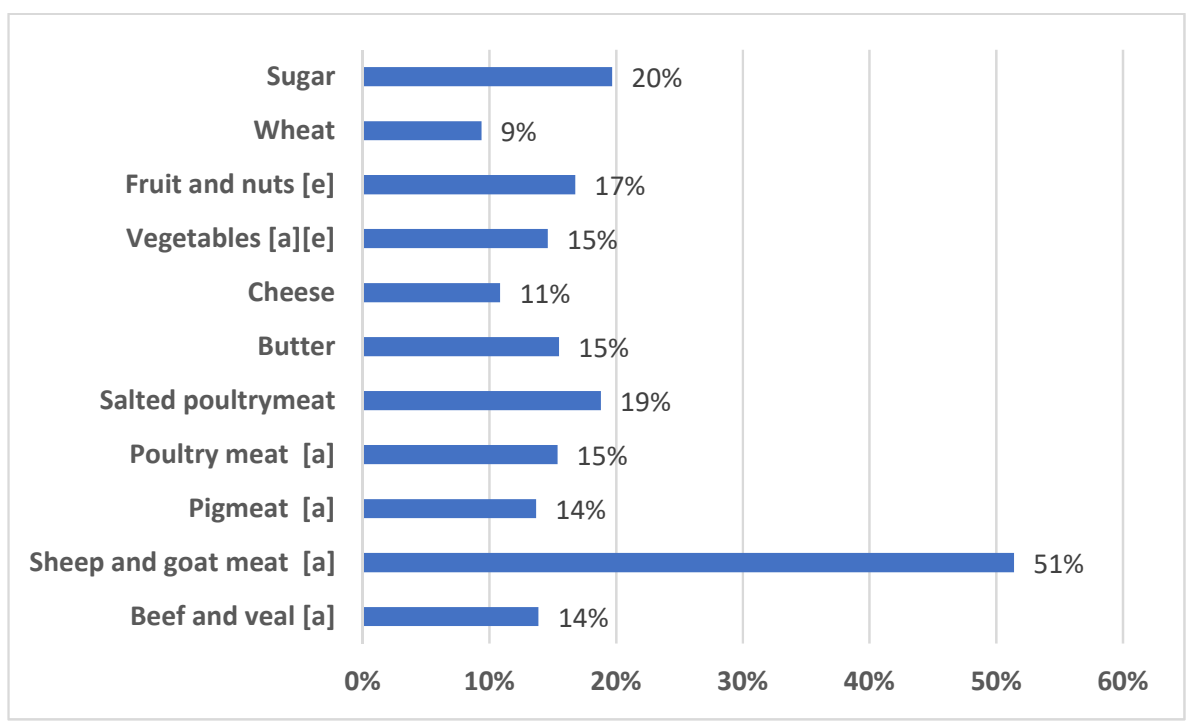

Notes: [a] fresh chilled and frozen including edible offals; [e] by value Source: Source: Adjusted EU EXTRA imports by tariff regime by HS2,4,6 and CN8 [DS-645593]; Accessible at http://ec.europa.eu/eurostat/web/international-trade-in-goods/data/database (Last accessed 18/04/2017)

Figure 2: UK self supply and EU27 share of UK imports 2013-15 average

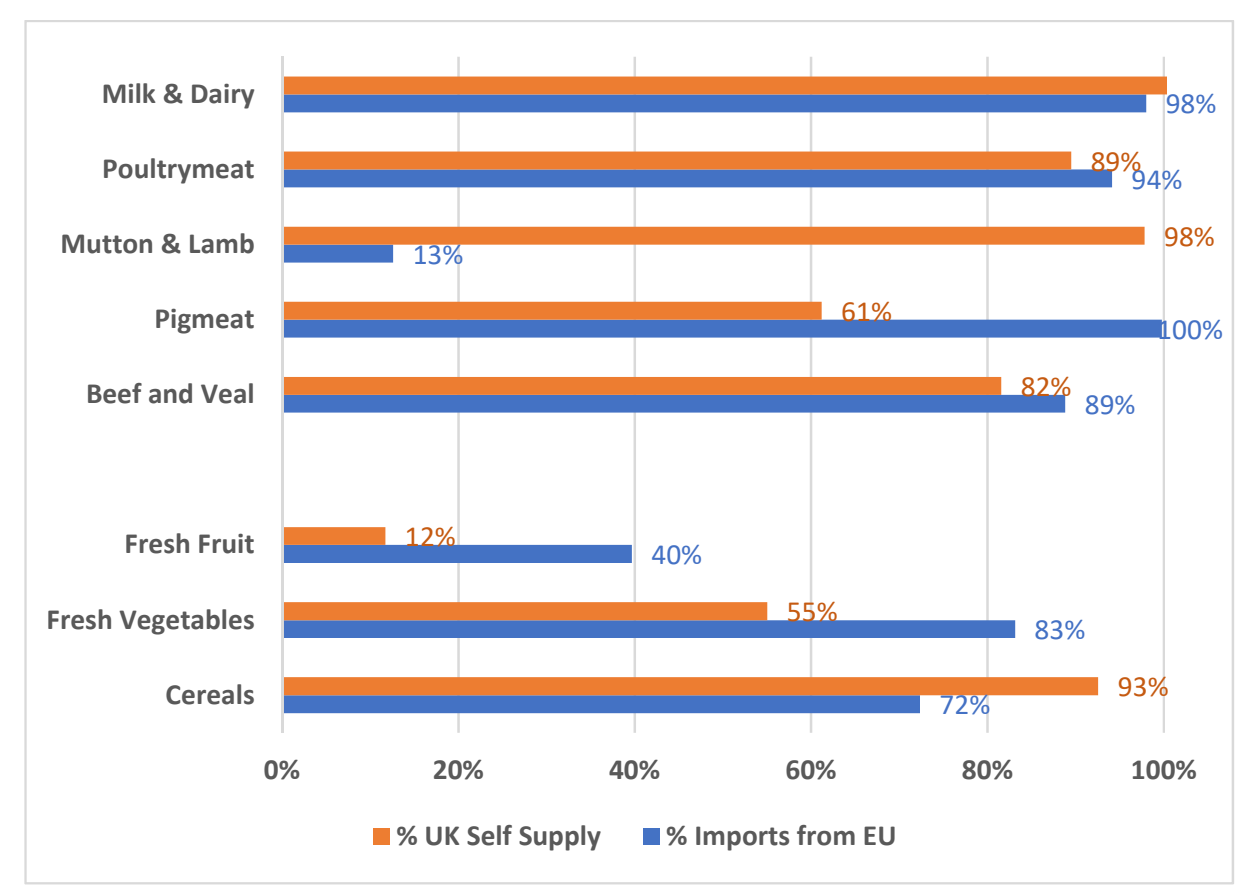

Source: Agriculture in the United Kingdom, 2015 Ch.7; Defra: National Statistics 2016. Author's calculations. Milk and Dairy relates only to butter and cheese, cereals to common wheat, barley and oats. 
Fig 3a: UK and TR quota holders shares of third country imports in 2015

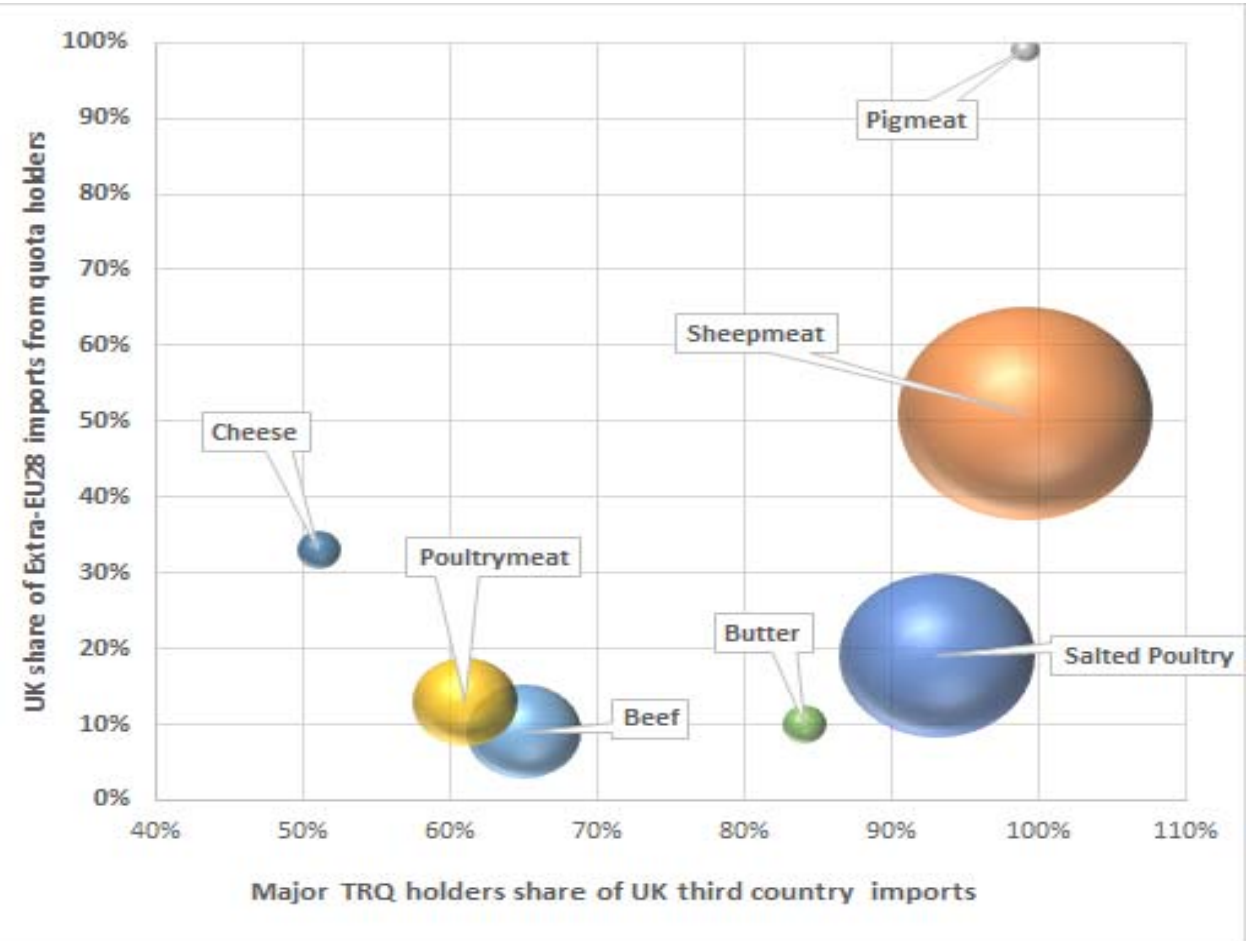

Sources: Adjusted EU extra imports by tariff regime by HS2,4,6 and CN8 [DS-645593]; author's calculations

Figure 3b: UK shares of EU28 imports in 2015 from principal meat and dairy TRQ holders

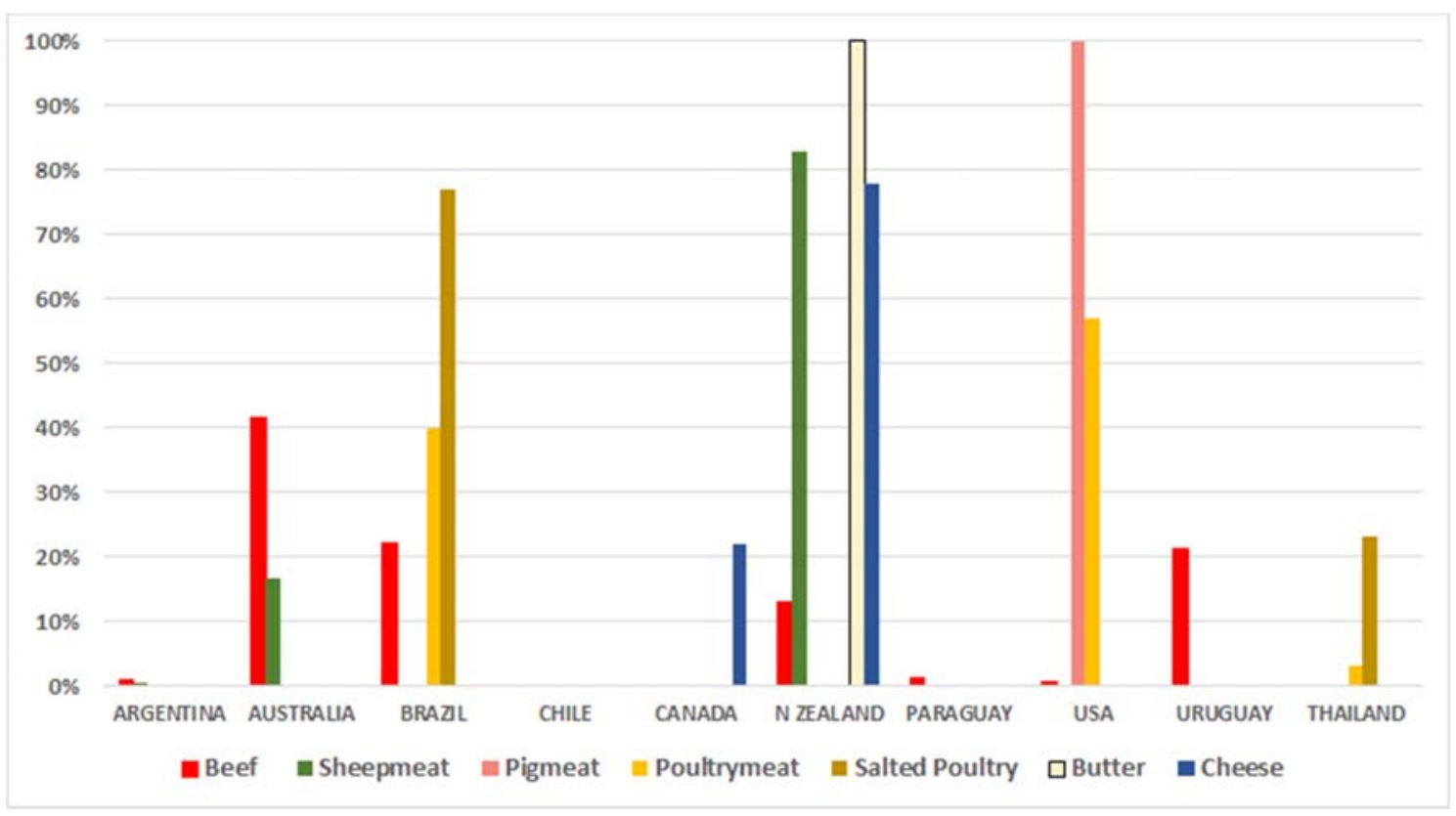

Sources: ibid Figure 3a 


\section{Summary}

Tariff rate quotas (TRQs) are a means by which non EU suppliers of agri-food products can be given preferential access to EU markets within a regulated framework of quotas at tariff rates below the Most Favoured Nation rates bound in the GATT. TRQs are common in governing trade in the meat and dairy sectors of the EU, although they apply to a wide range of other agricultural commodity and processed agri-food products. Brexit poses a complex set of problems regarding TRQs in terms of how the respective parties should divide up jointly undertaken commitments within the WTO, since TRQs have been negotiated by the Commission on behalf of all EU member states. Whilst individual quota allocations can be allocated to specific third country suppliers, individual member states receive no specific allocation of the global product TRQ either in total, or from any named preferential supplier. The article outlines the nature of TRQs in the meat and dairy sectors of the EU, and how a simple partitioning of existing quotas between the EU27 and UK is unlikely to resolve the complex issue of access rights of third countries to both markets. Possible solutions are explored, including the potential need for reciprocal EU27-UK TRQs post-Brexit.

\section{Pullquote}

"A swift resolution of any UK TRQs within or outside any bilateral trade agreements would appear to be optimistic" 